his methods till I saw his name in THE IJANCET of August 24th. My "discovery" so far as the Harrcgate sulphur waters are concerned is quite original. I am, Sins, yours faithfully,

Harrogate.

FraNCIS TYI SNITH

\section{"THE SALARY OF A MEDICAL OFFICER IN THE HIGHLANDS AND ISLANDS." To the Editors of THE LANCET.}

SIRs,-The attention of our client Dr. Donald Lamond, recently medical officer of the parish of Lochbroom, has been called to your issue of the 17th inst., in which you comment on the advertisement for a successor to him in that office. You copy the advertisement from the Glasgon Herald and state that you "do not recommend any medical man to apply for this vacancy without making full inquiry from the previous medical officer as to the work to be done." At the beginning of your note you state that the advertisement had been sent to you for comment and you close your comment by saying, "We are informed that the salary is totally inadequate."

From the terms of your remarks it is clear that some person with more than an outsider's knowledge of the appointment has sent the advertisement to you, and from your reference to the "previous medical officer" it might be inferred that our client was your informant. Our client regrets very much that you should have connected him in any way, however indirectly, with a paragraph the object of which is clearly to prevent the vacancy being filled up and he feels that he owes it to the parish council that he should ask you to make it quite clear in your next issue that your comments were not suggested by him.

We have advised our client to send a copy of this letter and of your reply to the Lochbroom Parish Council in case their attention may be drawn to your note and we shall therefore be obliged by your stating explicitly in your reply to us that our client ras not in communication with you as to the advertisement and that your comments were in no way suggested by him.

We shall be glad to hear from you.

We are, Sirs, your obedient servants,

Edinburgh, August 29th, 1901.

CAMERON AND ORR

$* *$ We have pleasure in publishing the above communication and in confirming the statement of Messrs. Cameron and Orr that their client was not in communication with us as to the advertisement. Our correspondent in the matter was perfectly well informed and our warning that no one should apply for this vacancy (or similar vacancies) without making inquiry from the previous medical officer is one that we very usually give. The fact that Dr. Donald Lamond happened to be the previous medical officer was an accidental circumstance.-ED. L.

\section{NOTES FROM INDIA.} (From our SPECIAL CORREspondent.)

\section{Further Inorease in Plague Hortality.-1 Ierer's Work of the Pasteur Institute at Kasauli. - The Health of Assom.-} Enteric Fever in the British Army.

THE rise in the number of plague deaths throughout India cluring the past week is very decided. For the week ending August 10th 2618 deaths were recorded, against 2003 in the preceding week and only 285 in the corresponding week of last year. The figures are : Bombay districts 2198 (especially Dharwar districts), against 1730; Bombay City 159, against 136; Mysore State 209, against 109; Calcutta 17, against 11 : and Bengal 10. against 4. These figures show that the disease is slumbering in Bengal but active again in Bornbay. The City of Hubli in Dharwar district is again attacked. It will be remembered that over two years ago plague ravaged this city very severely and that during the outbreak an enormous majority of the population were induced to undergo inoculation. Its comparative absence during the interval is strong evidence in favour of inoculation. Notwithstanding the adverse recommendations of the Plague Commission train inspection of all passengers from the Southern Mahratta Country has been re-instituted at Poona.
Sporadic cases continue in Karachi and in Poona. In Bombay city there has been a sttady rise for several weeks and the rate of mortality has been going up ont of als proportion to the reported increase of plague. The deatl: rate at present is recorded as 50.72 per 1000 .

The Pasteur Institute at Kasauli completed its first year: work on August 8th. The total number of patients has been 321-namely, 146 Europeans and 175 natives. There has not been a single failure in the treatment among the Europeans and only two amongst the natives. In the latter cases the patients had been severely bitten and arrived late for treat ment. The saving to the Government must have been considerable, as no British soldiers have been sent to Paris. The animals which inflicted wounds were dogs (the great majority), jackals, wolves, foxes. cats. ponies, and mules. In a large number of the cases the animals were experimentally proved to have had rabies. a portion of brain and spinal cord being sent to the institute to be tested. In other cases the animals were certified as rabid by veterinary surgeons. Many who were bitten by the same animals but did not come up for treatment died None of the patients were upset by the treatment or ill in any way. The recorc therefore is better than that of any similar institution in the world. At Cawnpore only a few days ao a mad jackal ran amok and bit 11 men amongst the 11th Rajputs and seren men and seven followers of the 5th Bengal Cavalry The whole party have been despatched to Kasauli.

Assam has always had a bad reputation for unhealthiness. This is not borne out by the sanitary reports for the province. The death-rate last year was 30.64 per 1000 , as compared with 31.34 for Bengal. There is a low death-rate from fever and even where the fatal kala azar abounds it was only $12 \cdot 07$, against 22.98 for all Bengal. In previous years, however, it has not been quite so good. The deaths from kala, azar have steadily declined from 18,597 in 1897 to 9012 in the year under review.

The health returns of British regiments in India continue to show a remarkable decline of enteric fever duxing the current year. It is important to remember that the garrisons consist at the present time mostly of seasoned soldiers, while only very small drafts have been received from England since 1899. This must be taken into account in comparing: with past years and in estimating the probable value of sanitary improvements. We must await the adrent of youngsoldiers to prove the value of the sanitary works effected during the past two years.

On the recommendation of the Director-General Indian Medical Service, the Government of India is distributing among civil surgeons and other merlical officers the work "Malaria according to the New Researches" by Professor Angelo Celli of Rome.

Bacteriological work is being started at several new places. The Port Commissioners at Rangoon propose building and equipping a laboratory chiefly at first for the examination of suspected plague. The Govermment of the Malay States has recently established a Research Institute open to alk workers irrespectire of nationality. Pathological work. original chemical research, as well as bacteriologicat investigations will be open to all. It is time that laboratories on a similar scale wcre started in some of the chief cities in India.

August 16th.

Preventive Inoculation for Rinderpest. - Famine Relicy:-Th: Health of the Three Presidential Citics: Sanitara Iniprovements in Caloutta.

THE prevalence of rinderpest in Bengal has given excellent opportunities to the Teterinary Department to test preventive inoculation of cattle. There are two methods in use-the single and double. The single, or plain serum method, consists in injecting a certain quantity of serum under the skin. This does not produce any reaction and the animals are able to be kept at work. The natives raise $n n$ objections to it and the operation is sufficiently simple to trust a veterinary assistant with it. The great disadvantage is that the protection afforded only lasts a short time, although tho immunity may extend throughout an epidemic. Even when it fails to protect completely it may be sufficient to prevent the death of the animal. The double method, consisting of an injection of serum on one side and an injection at the same operation of virulent rinderpest blood on the other side of the animal, possesses the advantage of conferring immunity for several years. On the other hand, it has many disadrantages. The native objects to the taking and using 